\title{
Management of imported malaria in Europe
}

\author{
Helena H Askling ${ }^{1,2}$, Fabrice Bruneel ${ }^{3}$, Gerd Burchard ${ }^{4}$, Francesco Castelli ${ }^{5}$, Peter L Chiodini ${ }^{6}$, Martin P Grobusch ${ }^{7}$, \\ Rogelio Lopez-Vélez ${ }^{8}$, Margaret Paul ${ }^{9}$, Eskild Petersen ${ }^{10^{*}}$, Corneliu Popescu $^{11}$, Michael Ramharter ${ }^{12}$ and \\ Patricia Schlagenhauf ${ }^{13}$ on behalf of the European Society for Clinical Microbiology and Infectious Diseases \\ Study Group on Clinical Parasitology
}

\begin{abstract}
In this position paper, the European Society for Clinical Microbiology and Infectious Diseases, Study Group on Clinical Parasitology, summarizes main issues regarding the management of imported malaria cases. Malaria is a rare diagnosis in Europe, but it is a medical emergency. A travel history is the key to suspecting malaria and is mandatory in patients with fever. There are no specific clinical signs or symptoms of malaria although fever is seen in almost all non-immune patients. Migrants from malaria endemic areas may have few symptoms. Malaria diagnostics should be performed immediately on suspicion of malaria and the gold- standard is microscopy of Giemsa-stained thick and thin blood films. A Rapid Diagnostic Test (RDT) may be used as an initial screening tool, but does not replace urgent microscopy which should be done in parallel. Delays in microscopy, however, should not lead to delayed initiation of appropriate treatment. Patients diagnosed with malaria should usually be hospitalized. If outpatient management is preferred, as is the practice in some European centres, patients must usually be followed closely (at least daily) until clinical and parasitological cure. Treatment of uncomplicated Plasmodium falciparum malaria is either with oral artemisinin combination therapy (ACT) or with the combination atovaquone/proguanil. Two forms of ACT are available in Europe: artemether/lumefantrine and dihydroartemisinin/ piperaquine. ACT is also effective against Plasmodium vivax, Plasmodium ovale, Plasmodium malariae and Plasmodium knowlesi, but these species can be treated with chloroquine. Treatment of persistent liver forms in $P$. vivax and $P$. ovale with primaquine is indicated after excluding glucose 6 phosphate dehydrogenase deficiency. There are modified schedules and drug options for the treatment of malaria in special patient groups, such as children and pregnant women. The potential for drug interactions and the role of food in the absorption of anti-malarials are important considerations in the choice of treatment.

Complicated malaria is treated with intravenous artesunate resulting in a much more rapid decrease in parasite density compared to quinine. Patients treated with intravenous artesunate should be closely monitored for haemolysis for four weeks after treatment. There is a concern in some countries about the lack of artesunate produced according to Good Manufacturing Practice (GMP).
\end{abstract}

\section{Background}

Malaria continues to pose challenges in diagnosis and management and remains an infrequently encountered infection for many physicians in non-endemic areas. Malaria symptoms are non-specific and cannot easily be distinguished from a wide range of other febrile conditions on clinical grounds alone [1]. Thus, a high degree of suspicion is needed and a travel history is essential in

\footnotetext{
* Correspondence: eskildp@dadlnet.dk

${ }^{10}$ Department of Infectious Diseases, Aarhus University Hospital Skejby, Aarhus, Denmark

Full list of author information is available at the end of the article
}

any febrile patient presenting with non-specific, often flu-like symptoms and signs.

Malaria cannot be confirmed clinically. The gold standard for malaria diagnosis is light microscopy of Giemsa-stained thin and thick blood films, which requires a high level of expertise. This is not always available around the clock outside specialized centres and rapid diagnostic tests (RDTs) are, therefore, increasingly used. However, RDTs have limitations and once a malaria diagnosis has been made, the infecting species present must be determined. Furthermore, in the case of Plasmodium falciparum or Plasmodium knowlesi, the

\section{Biomed Central}


parasitaemia (expressed as number of parasites per microlitre of blood or as a percentage of red cells infected) is an essential parameter for determining whether the patient has complicated malaria or not, and to monitor treatment effect.

The management of malaria in non-endemic areas may vary between centres. For example, in a retrospective analysis of over 500 patients from five European countries treated between 2003 and 2009, 18 different combination regimens were used [2]. To standardize management based on current evidence, this paper reviews malaria management for non-specialists and advocates how it should be practised in Europe.

\section{Short epidemiology of imported malaria}

Malaria is one of the major global public health challenges with an estimated 225 million clinical cases and more than 655.000 deaths in 2011, mainly in children aged less than five years old from sub-Saharan Africa. However, recent studies have found that the mortality may be grossly underestimated $[3,4,5]$. In Europe, malaria has been eradicated except in Azerbaijan, Georgia, Kyrgyzstan, Tajikistan and Turkey [6]. It is estimated that 25-30 million individuals travel annually from Europe to areas with malaria transmission.

Malaria imported to Europe is seen in travellers returning from or migrants coming from endemic areas and migrants living in Europe returning from visiting friends and relatives (VFR). VFR children are particularly at risk. In 2010, WHO reports that 6,244 cases of malaria were imported in Europe down from 14,703 cases in 2000 [6], however, this is considered to be an underestimation and the numbers may be six-fold greater [3] and this decrease in numbers contradicts national studies, which all indicate an increasing number of imported cases. Latest data from the UK [7] and Europe [8] show increasing trends in imported malaria and the latest US statistics show an increase of $14 \%$ in imported malaria for 2010 [9]. The majority of imported cases remains uncomplicated [1], and the mortality of imported Plasmodium falciparum malaria cases varies from $0.4 \%$ in a large cohort from France up to $5 \%$ in a recent cluster of cases imported from The Gambia [10,11].

The malaria programme in the WHO European Region, reported an eight-fold increase in the number of imported malaria cases between 1972 and 1988 (from 1,500 to 12,000 cases), followed by a more gradual rise in 2000 (15,500 cases) with France, the UK, Germany and Italy accounting for more than $70 \%$ of all cases [12]. One study found that the crude risk for travellers varied from 1 per 100,000 travellers to Central America and the Caribbean to 357 per 100,000 in Central Africa [13].
More than five million African migrants may currently be living in Europe, one third of them originating from sub-Saharan Africa [14]. The proportion of imported malaria cases due to migrants in Europe has increased during recent years from $14 \%$ to $83 \%$ [15-18]. VFRs travelling to sub-Saharan Africa have more than eight times the risk of being diagnosed with malaria compared to tourists, and more than twice the odds of being diagnosed of malaria after travel to Asia [19]. VFR children are particularly at risk [20].

Malaria infection among migrants, for example, asymptomatic individuals with sub-microscopic parasitaemia, could increase the risk of transmission leading to re-introduction of malaria in certain areas that have competent vectors and climatic conditions as seen in Greece in 2011 [21]. Moreover, imported malaria infections in migrants can also play a role in non-vectorial transmission, through blood transfusion, organ transplantation or occupational exposure.

Migrants commonly believe they are immune to malaria [22], but their immunity wanes after arriving in Europe. The low risk perception means that this group rarely seeks pre-travel advice [7,23-25]. The incidence of $P$. ovale infections and mixed infections is very similar to the incidence found in West Africans [26-29].

Rare modes of transmission mean that patients with fever and without a travel history to endemic areas might need to be tested for malaria. These include so called "airport malaria" where Anopheles mosquitoes carrying malaria parasites are transported by aeroplane to a non-endemic area and take a blood meal from someone living close to the destination airport [30,31], and "baggage malaria" [32]. Malaria parasites can also be transmitted in blood as a consequence of intravenous drug use [33]. Transmission of malaria by blood transfusion from asymptomatic carriers is a major problem in tropical Africa [34] and febrile patients with a history of blood transfusion from a donor in or from a malariaendemic area should be suspected to have malaria until proven otherwise. Congenital transmission or transmission by organ transplantation may also occur [35].

\section{Pathophysiology}

The pathophysiology of malaria involves the cytoadherence of infected erythrocytes (discussed below) and consequent microvascular obstruction, as well as destruction of infected erythrocytes and the host's response to the released substances. Chills and fever are associated with high levels of tumour necrosis factor released from monocytes stimulated by antigens released by bursting schizonts. Thrombocytopenia may be immunemediated or due to activation of the coagulation cascade [36]. Anaemia is a consequence of intravascular lysis of 
infected erythrocytes, impaired bone marrow responses and increased clearance of uninfected red cells.

P. falciparum-infected erythrocytes adhere to microvascular endothelium in a process known as sequestration, which allows them to avoid being removed in the spleen. This is favoured by other processes, such as a reduction of red cell deformability, rosetting of noninfected erythrocytes around the infected erythrocytes, platelet-mediated aggregation of infected erythrocytes [37-41]. Sequestration is seen especially in the small venules of vital organs (brain - predominantly in white matter, heart, lung, liver, kidneys, eyes) [42,43]. Sequestering of the erythrocytes in areas with low oxygen tension may favour survival of the parasites. It has been proposed that cerebral malaria is part of a heterogeneous clinical presentation involving multi-system dysfunction and acidosis [44]. A study of volume depletion in children with malaria demonstrated that lactate (arterial) was increased at admission [45], that volume depletion was not severe and that lactate is the best indicator for tissue perfusion and acidosis.

\section{Clinical symptoms \\ Clinical symptoms in non-immunes (persons not born and raised in endemic areas)}

Most infections due to $P$. falciparum become symptomatic within 30 days after return from the malaria endemic area, but longer incubation periods are seen with the other species and are prolonged by incomplete malaria chemoprophylaxis which may suppress parasitaemia without achieving full protection. A recent study from Portugal including 284 patients (46\% nonimmunes and $54 \%$ semi-immunes) found that the diagnosis was made between the day of return from the malarious area and up to 47 days later; a single nonimmune patient was first diagnosed on the 120th day after leaving Angola [46].

Prodromal symptoms, which may precede the fever for up to two days are fatigue, loss of appetite, headache and body pains. In non-immune patients, malaria usually starts suddenly with a severe feeling of sickness and fever - often reaching $39^{\circ} \mathrm{C}$ and higher [1]. Not all patients show typical fever paroxysms and absence of fever does not remove the suspicion of malaria in an ill patient. A regular fever pattern is not always present. If present, the frequency of the febrile episodes depends on the parasite species, occurring every 48 hours (tertian) for $P$. vivax and $P$. ovale, every 72 hours (quartan) for $P$. malariae and 24 hours (quotidian) for $P$. knowlesi. In P. falciparum malaria the fever usually lacks a regular pattern.

Common symptoms are headache and myalgia. Other symptoms may include nausea, vomiting, dry cough, icterus, confusion and respiratory distress. Compromised circulation leads to renal failure and impaired tissue perfusion resulting in acidosis. Gastrointestinal complaints unrelated to treatment, including vomiting and diarrhoea are less frequent. Patients with significant fever paroxysms may initially have a normal temperature between the fevers and feel relatively well.

Clinical examination is non-specific or even completely unremarkable. It often takes some days before anaemia or hepatosplenomegaly develop. Coryza, swelling of lymph nodes and eosinophilia are not seen in malaria.

\section{Clinical symptoms in persons migrating from malaria endemic areas}

Malaria in adult migrants is characterized by a milder clinical presentation, lower levels of parasitaemia, shorter parasite clearance time after treatment and shorter fever duration compared to malaria in travellers due to previously acquired semi-immunity [29,47-49]. Children born in Europe to migrant parents are not immune.

A high proportion of migrants have few symptoms and present long after arrival in the host country [50], with periods of months up to more than 14 years recorded [50-54]. If semi-immunity is lost, migrants who travel to their country of origin would have a risk of clinical malaria approaching that of travellers born in non-endemic countries, however a degree of clinical immunity against severe malaria is often retained. A high prevalence (from $7.1 \%$ to $31.8 \%$ ) of P. falciparum infection (detected by PCR) has been found among asymptomatic sub-Saharan African migrants after their migration to Europe $[48,55,56]$.

\section{Indications for malaria diagnosis}

Diagnostic tests for malaria should be performed in any ill patient who has a history of exposure, i.e. patients with a history of travel to malaria-endemic areas, whether or not they are febrile at presentation [57].

Pregnant women visiting endemic areas or arriving from areas of malaria transmission are at greater risk of clinical malaria during pregnancy [50] than non-pregnant women. Malaria parasites cross the placenta and consequently the disease can occur in newborns from asymptomatic mothers [58,59]. Splenectomized patients may have more severe symptoms [60].

\section{Laboratory results (other than tests for malaria parasites)}

Most parameters are non-specific. Normochromic normocytic anaemia is observed in the majority of infected patients, but is rare in the first few days of illness. The most consistent finding is thrombocytopaenia and a study from the UK found that children with malaria and a platelet count of $<50,000$ per $\mathrm{ml}$ had an odds ratio of 8.3 for admission to intensive care units [61]. As the 
infection progresses, haemolysis is indicated by elevated $\mathrm{LDH}$, free haemoglobin and low haptoglobin.

Although commonly unaffected except in case of a secondary infection (often with non-typhoidal salmonellae), the leucocyte count may be raised or greatly diminished in very severe malaria cases and there may be slight monocytosis and lymphocytopenia. The C-reactive protein, procalcitonin, fibrinogen, orosomucoid and cytokine levels are raised in acute malaria. Thrombocytopaenia with a lower concentration of fibrinogen and elevated fibrin degradation products strongly suggest disseminated intravascular coagulation (DIC). Moderate hyponatraemia can be seen, but plasma potassium level is normal [62]. Bicarbonate concentration is reduced and lactate may be elevated in metabolic acidosis, and arterial lactate is a better marker for acidosis than venous standard bicarbonate. Serum creatinine and urea, total and conjugated bilirubin and liver transaminases may be raised, and a slight elevation of hepatic alkaline phosphatase may be seen. Hypoglycaemia may occur and, in the absence of quinine treatment is accompanied by other signs related to high parasitaemia and severe acidosis

Table 1 Laboratory indicators of a poor clinical prognosis in severe malaria

\begin{tabular}{|c|c|}
\hline \multirow[t]{3}{*}{ Hyperparasitaemia: } & $\begin{array}{l}>250.000 / \text { ul or }>2 \% \text { of infected } \\
\text { erythrocytes in non-immunes and } \\
>5 \% \text { in semi-immune individuals }\end{array}$ \\
\hline & $\begin{array}{l}\text { Schizonts of } P \text {. falciparum in } \\
\text { peripheral blood }\end{array}$ \\
\hline & $\begin{array}{l}\text { Mature pigmented parasites (> 20\% } \\
\text { of parasites) }\end{array}$ \\
\hline Peripheral blood leukocytes & with ingested hemozoin (>5\%) \\
\hline Haemoglobin & $<5 \mathrm{~g} /$ dl or packed cell volume $<0.15$ \\
\hline Polymorphonuclear leukocytes & $>12.000 / u l$ \\
\hline \multirow[t]{5}{*}{ Coagulation disturbancies } & Platelets $<50.000 /$ ul \\
\hline & Prothrombin time prolonged $>3 \mathrm{sec}$ \\
\hline & Prolonged partial thromboplastin time \\
\hline & Fibrinogen $<200$ mg/dl \\
\hline & Low antithrombin III levels \\
\hline Hypoglycaemia & $<2.2 \mathrm{mmol} / \mathrm{l}(<40 \mathrm{mg} / \mathrm{dl})$ \\
\hline \multirow[t]{2}{*}{ Acid-base disturbancies } & $\begin{array}{l}\text { Venous } \mathrm{HCO} 3<15 \mathrm{mmol} / \mathrm{l} \text { and/or } \\
\text { arterial } \mathrm{pH}<7.3\end{array}$ \\
\hline & Lactate $>5 \mathrm{mmol} / \mathrm{l}$ \\
\hline \multirow[t]{2}{*}{ Kidney function } & $\begin{array}{l}\text { Serum creatinine }>3.0 \mathrm{mg} / \mathrm{dl} \\
(>265 \mathrm{mmol} / \mathrm{l})\end{array}$ \\
\hline & Blood urea nitrogen $>60$ mg/dl \\
\hline Liver function & $\begin{array}{l}\text { More than 3-fold elevation of } \\
\text { aminotransferases (AST, ALT) }\end{array}$ \\
\hline Cerebrospinal fluid & $\begin{array}{l}\text { High CSF lactic acid (> } 6 \mathrm{mmol} / \mathrm{l}) \\
\text { and low CSF glucose concentration }\end{array}$ \\
\hline
\end{tabular}

[63]. Laboratory indicators of a poor clinical prognosis in severe malaria cases are shown in Table 1.

Blood cultures should be obtained on admission as malaria infection can be complicated by septicaemia $[64,65]$. All patients with malaria should have the following obtained at the time of diagnosis: haemoglobin, MCV, $\mathrm{MCHC}$, differential leucocyte count, platelets, blood urea nitrogen or creatinine, alanine transferase, basic phosphatase and LDH. In complicated malaria this should be supplemented with tests for DIC and arterial blood for $\mathrm{pH}$, lactate (arterial), blood gases and blood cultures. Additional potentially useful parameters include chest $\mathrm{x}$-ray, urine culture and urine leukocytes, ECG, potassium, urea, ALT, LDH, haptoglobin, fibrinogen.

\section{Diagnostic procedures for malaria parasites including parasitaemia}

Microscopic examination of Giemsa-stained thin and thick blood films remains the gold standard because it is rapid, easy to perform and sensitive [66] with a sensitivity down to five parasites per microlitre in expert hands [67]. Thick blood films are combined with thin blood films as identification of the infecting species is much more easily accomplished using a well-stained thin film. However, the volume of blood examined in 100 high power fields on a thick blood film is approximately 50 times more than in 100 high power fields of a thin blood film, so malaria cannot be excluded based on negative examination of only a thin blood film.

Early diagnosis is important to prevent uncomplicated malaria progressing to complicated disease. Patients with malaria should be managed in centres with the ability to quantify the parasitaemia (usually expressed as the number of parasites per microlitre of blood or as the percentage of red cells containing malaria parasites). After the start of treatment, there is a lag-phase before the parasite density begins to decline [68] and there may even be an increase in the first 24 hours after starting treatment.

For falciparum malaria, many RDTs show $100 \%$ parasite detection score down to a parasite density level of 200 parasites per microlitre, equivalent to a parasitaemia of approximately $0.004 \%$ [69]. Polymerase chain reaction (PCR) can detect parasites down to a density of 0.01 parasites per microlitre after a lysis procedure and 1 parasite per microlitre without lysis [70]. However, PCR analysis is not instantly available around the clock so in practice, diagnosis relies on RDTs and light microscopy of Giemsa-stained thin and thick blood films. PCR is, however, very useful in partially treated cases, in submicroscopic malaria in immigrants and in detection of mixed parasitaemia.

RDTs are increasingly used in medical centres with limited access to experienced microscopists, however, 
a rapid test cannot determine the parasite density. False negative RDTs in patients with very high parasite densities have been described, probably due to the socalled "pro-zone" phenomenon [71,72]. This problem seems to be limited to tests based on detection of Histidine Rich Protein 2, HRP2 [71]. Mutations in the HRP2 gene may also result in false negative tests [73,74] and rheumatoid factor may lead to false positives [75]. Assays are available that detect all species i.e. P. falciparum, P. vivax, P. ovale, P. malariae, and P. knowlesi based on the detection of pan-malarial antigens aldolase and LDH antigen [76]. Plasmodium knowlesi infections will be detected by rapid tests which include the pan plasmodial aldolase or LDH antigens $[69,77]$. The latest results of the WHO multi-centre evaluation of different rapid diagnostic tests show that the best performance was found with tests based on a combination of the HRP2 and pan plasmodial proteins [69]. Clinicians using rapid tests should be instructed that no RDT test so far is $100 \%$ reliable and that they should be used in parallel to and not instead of blood film examination. In order to reduce the risk of missing malaria, testing with blood films and RDTs should be performed on three blood samples taken at daily intervals for patients with high suspicion for malaria. If the suspicion of malaria remains after three negative samples, expert advice should be obtained from a tropical or infectious diseases specialist. Once the diagnosis has been made, the patient should have daily blood films until they are negative for asexual parasites (ie. rings, trophozoites, schizonts). Gametocytes do not multiply or cause clinical illness and may remain after clearance of the asexual parasitaemia.

\section{Treatment of uncomplicated $P$. falciparum malaria}

Treatment should provide rapid clinical and parasitological cure within three days. Oral ACT is the standard treatment of uncomplicated malaria as recommended by WHO [78,79] (Table 2). Currently, artemether/lumefantrine, and dihydroartemisinin/piperaquine, a ACT formulation registered by the European Medicines Agency, EMA, are licensed for use in Europe. Artemether/lumefantrine is the most widely-used ACT globally, is well tolerated and highly efficacious in all endemic regions except for P. falciparum infections acquired in Cambodia and the border regions of Thailand with Myanmar, where multidrug resistant $P$. falciparum strains are highly prevalent.

Artemether/lumefantrine has to be administered with fatty food to obtain optimal plasma drug concentrations [80]. Dihydroartemisinin/piperaquine is a newly registered ACT with proven high efficacy and a favourable tolerability profile. It has been extensively used in malaria-endemic regions and marketing in European countries has started. Dihydroartemisinin/piperaquine should be taken fasting (Table 3 ).
Atovaquone-proguanil can be used as first-line treatment for uncomplicated malaria and needs to be administered with fatty food to increase bioavailability (Table 3). Atovaquone/proguanil is relatively slow acting with considerably longer parasite clearance times compared to ACT (Table 4). Atovaquone/proguanil is the preferred treatment option for uncomplicated falciparum malaria from regions with artemisinin resistance (Cambodia, Thailand border regions).

Second-line anti-malarial treatments used when firstline anti-malarials are not available or excluded due to other reasons such as intolerance include mefloquine monotherapy for infections originating from regions without established mefloquine resistance (high prevalence of mefloquine resistance is common in Thailand, Myanmar and Cambodia). The use of mefloquine at treatment doses has been associated with a significantly higher incidence of serious neuropsychiatric adverse events [81]. Combinations of quinine with either doxycycline or clindamycin are also considered second line treatment options.

Quinine drug combinations have excellent efficacy, but tolerability is generally poor due to prolonged treatment courses and the occurrence of characteristic adverse effects (cinchonism) [82]. The WHO guidelines consider quinine plus tetracycline or clindamycine as alternative first-line treatments, but the study group is of the opinion that ACT should be the first line choice in Europe [79].

The use of chloroquine is not recommended for the treatment of $P$. falciparum malaria because of widespread resistance. However, chloroquine remains effective in Haiti, Dominican Republic, Middle East and Central America north of the Panama Canal, and may be considered as an alternative treatment if ACT cannot be used.

In the case of failed anti-malarial chemoprophylaxis, an anti-malarial drug different from the chemoprophylactic drug taken should be used for treatment. Finally, it is important to note that despite the fact that oral anti-malarials are recommended for the treatment of uncomplicated malaria, it is sometimes necessary for the responsible physician to use intravenous treatment with artesunate or quinine as recommended for the treatment of severe malaria. This decision may be taken based on evidence of important co-morbidities, intractable vomiting, or on clinical concern of the physician. The clinical criteria for severe malaria are shown in Table 4. Recently, the WHO defined a parasitaemia of $2 \%$ or more as severe malaria in non-immunes and $5 \%$ or more in patients from endemic areas [79].

Patients suffering from $P$. falciparum malaria should, in general, be admitted to hospital, since monitoring of prognostic parameters including parasitaemia, treatment 
Table 2 Treatment of uncomplicated falciparum malaria in adults [79]

\begin{tabular}{|c|c|c|c|}
\hline & $\begin{array}{l}\text { Adult Patients } \\
\text { Drug }\end{array}$ & Dosage & Comment \\
\hline \multirow[t]{3}{*}{ First line } & Artemether/Lumefantrine (Riamet ${ }^{\mathrm{TM} M}$ ) & $\begin{array}{l}\text { Twice daily for three days }>35 \mathrm{~kg} \text { : } \\
4 \text { tablets each } 20 \mathrm{mg} / 120 \mathrm{mg} \text { for } \\
6 \text { doses (0-8-24-36-48-60 hours) }\end{array}$ & $\begin{array}{l}\text { Take with fatty food, reduced efficacy } \\
\text { in Cambodia and border regions } \\
\text { of Thailand }\end{array}$ \\
\hline & $\begin{array}{l}\text { Dihydroartemisinin/Piperaquine } \\
\left(\text { Eurartesim }^{T M}\right)^{\circ}\end{array}$ & $\begin{array}{l}\text { Once daily for three days } 36<75 \mathrm{~kg} \text { : } \\
3 \text { tablets each } 320 \mathrm{mg} / 40 \mathrm{mg} \text {, } 75-100 \mathrm{~kg} \text { : } \\
4 \text { tablets each } 320 \mathrm{mg} / 40 \mathrm{mg} \text {, daily for three days }\end{array}$ & $\begin{array}{l}\text { Administration without food, at least } \\
3 \text { hours from any meal }\end{array}$ \\
\hline & Atovaquone/Proguanil (Malarone ${ }^{\mathrm{TM}}$ ) & $\begin{array}{l}\text { Once daily for } 3 \text { days }>40 \mathrm{~kg}: 4 \text { tablets } \\
\text { each } 250 / 100 \mathrm{mg}\end{array}$ & Administration with fatty food \\
\hline \multirow[t]{3}{*}{ Second line } & Quinine*/Doxycycline & $\begin{array}{l}\text { Thrice daily } 10 \mathrm{mg} / \mathrm{kg} \text { quinine plus } \\
\text { daily } 200 \mathrm{mg} \text { doxycycline for } 7 \text { days }\end{array}$ & Loose drug combination, off-label use \\
\hline & Quinine*/Clindamycin & $\begin{array}{l}\text { Thrice daily } 10 \mathrm{mg} / \mathrm{kg} \text { quinine plus twice } \\
\text { daily } 10 \mathrm{mg} / \mathrm{kg} \text { clindamycin for } 7 \text { days }\end{array}$ & Loose drug combination, off-label use \\
\hline & Mefloquine (Lariam ${ }^{T M}$ ) & $\begin{array}{l}\text { Split total dose in } 2-3 \text { doses } 6-8 \text { hours } \\
\text { apart } 45-60 \mathrm{~kg}: 5 \text { tablets }(3+2 \text { tablets }) \\
>60 \mathrm{~kg}: 6 \text { tablets }(3+2+1 \text { tablets })\end{array}$ & $\begin{array}{l}\text { Administration after food intake } \\
\text { monotherapy, which is not suitable } \\
\text { for regions with multidrug resistant } \\
\text { falciparum malaria (SE-Asia) }\end{array}$ \\
\hline
\end{tabular}

${ }^{*}$ Quinine dose provided as quinine sulphate ${ }^{\circ}$ Eurartesim tablet strengths are Dihydroartemisinin/piperaquine $20 \mathrm{mg} / 160 \mathrm{mg}$ and Dihydroartemisinin/piperaquine $40 \mathrm{mg} / 320 \mathrm{mg}$.

adherence and if needed, transfer to intensive care units, would normally be instantly available. Repeated monitoring of blood pressure, urinary output and oxygen saturation may be indicated. However, management as outpatients may be considered in uncomplicated cases in some healthcare systems where daily follow up until clearance of parasitaemia and fever and monitoring of treatment adherence can be undertaken. Persons migrating from malaria endemic regions may fall into this category.

\section{Treatment of complicated falciparum malaria}

The clinical criteria for severe malaria are shown in Table 4. Severe malaria may also be caused by species other than P. falciparum, especially P. knowlesi. Plasmodium vivax can be severe in non-immunes [83]. The criteria for the definition of severe malaria were determined by studies carried out in endemic areas and their relevance to imported malaria in Europe remains controversial. However, these criteria may be adapted to the European context [84].

\section{Choice of drugs}

Severe imported P. falciparum malaria is an emergency which may become rapidly fatal [85]. Intravenous artesunate is the drug of choice [79] and a recent Cochrane review concluded that treatment with artesunate significantly reduced the risk of death both in adults (RR 0.61, 95\% Confidence Interval (CI) 0.50 to $0.75 ; 1664$ participants, five trials) and children (RR $0.76,95 \%$ CI 0.65 to 0.90; 5765 participants, four trials) [86]. Intravenous artesunate must be started immediately after the confirmation of the diagnosis and the patients transferred to the ICU for management.

\section{Intravenous artesunate (IVA)}

IVA is superior to intravenous quinine (IVQ) in overall survival and safer and simpler to administer [86-89]. IVA contains artemisinin hemisuccinate $60 \mathrm{mg} / \mathrm{ml}$ and is reconstituted with 3 to $5 \mathrm{ml}$ dextrose $5 \%$ and immediately administered in a bolus. IVA is administered as $2.4 \mathrm{mg}$ per kilogram of body weight every 12 hours on

Table 3 Important food - anti-malarial drug interactions

\begin{tabular}{|c|c|c|c|}
\hline Drug & Dietary recommendations & Mechanism of interaction & Practical consequence \\
\hline Atovaquone & Take with fatty meal & Increased solubility and absorbtion & Increased drug levels \\
\hline Artemether/lumefantrine & Take with food & Lumefantrine is lipophilic (fat soluble) & Up to 16 -fold increased drug levels \\
\hline Dihydroartemisinin/piperaquine & $\begin{array}{l}\text { Take on an empty stomach } \\
\text { (fasting) }\end{array}$ & Food increases absorption of piperaquine & Reduces risk of QTc prolongation \\
\hline Doxycycline & Without milk & $\begin{array}{l}\text { Milk chelates tetracyclines and reduces } \\
\text { absorption }\end{array}$ & $\begin{array}{l}\text { Low drug concentrations and } \\
\text { treatment failure }\end{array}$ \\
\hline Mefloquine & With food & Increased solubility and absorbtion & Increased drug levels \\
\hline Primaquine & With food & Increased solubility and absorbtion & Increased drug levels \\
\hline
\end{tabular}


Table 4 Severe manifestations of $P$. falciparum malaria in adults (WHO 2000, adapted WHO 2011) [77,78]

\begin{tabular}{|c|c|c|}
\hline Prognostic value & $\begin{array}{l}\text { Clinical manifestations and } \\
\text { laboratory findings }\end{array}$ & Frequency \\
\hline (?) no data & Prostration & +++ \\
\hline+ & $\begin{array}{l}\text { Impaired consciousness } \\
\text { (score }<11 \text { on the Glasgow Coma Scale) }\end{array}$ & ++ \\
\hline+++ & Acute respiratory distress & + \\
\hline++ & Multiple seizures & + \\
\hline+++ & $\begin{array}{l}\text { Circulatory collapse (systolic blood } \\
\text { pressure }<80 \mathrm{~mm} \mathrm{Hg} \text { with features of } \\
\text { peripheral circulatory failure) }\end{array}$ & + \\
\hline+++ & Pulmonary oedema (radiological) & + \\
\hline++ & Abnormal bleeding (clinically defined) & + \\
\hline+ & $\begin{array}{l}\text { Jaundice (clinically defined or serum } \\
\text { bilirubin }>50 \mathrm{~mol} / \mathrm{L}\end{array}$ & +++ \\
\hline+ & Macroscopic haemoglobinuria & + \\
\hline+ & $\begin{array}{l}\text { Severe anaemia (haemoglobin } \\
<5 \mathrm{~g} / \mathrm{dL} \text { or haematocrit }<15 \% \text { ) }\end{array}$ & + \\
\hline+++ & $\begin{array}{l}\text { Hypoglycaemia (blood glucose } \\
\text { concentration }<2.2 \mathrm{mmol} / \mathrm{L} \text { ) }\end{array}$ & ++ \\
\hline+++ & $\begin{array}{l}\text { Acidosis ( } \mathrm{pH}<7.35 \text { or plasma } \\
\text { bicarbonate }<15 \mathrm{mmol} / \mathrm{L} \text { ) }\end{array}$ & ++ \\
\hline+++ & High plasma lactate (>5 mmol/L) & ++ \\
\hline++ & $\begin{array}{l}\text { High parasitemia (especially } 2 \% \\
\text { in non-immune patients and } 5 \% \\
\text { in semi-immune patients) }\end{array}$ & + \\
\hline++ & $\begin{array}{l}\text { Acute renal failure } \\
\text { (serum creatinine }>265 \mu \mathrm{mol} / \mathrm{L} \text { and } \\
\text { 24-hour urine output }<400 \mathrm{~mL} \text { ) }\end{array}$ & +++ \\
\hline
\end{tabular}

day 1 and then once daily up to the total dose of $12 \mathrm{mg}$ per kilogram administered in five doses over 3 days [80]. IVA should be the drug of choice for treatment of severe imported malaria in Europe even though trials have only been performed in endemic regions [89]. A recent study reported haemolytic anaemia in six out of 25 patients treated with IVA for severe imported malaria diagnosed 14-31 days after the first dose of IVA [90]. A larger study including 55 patients with severe malaria reported late onset haemolytic anaemia in six patients $(9 \%)$ between 7 and 31 days after start of IVA [91] and three more cases have just been reported [92]. Nevertheless, in a large French study about 400 severe malaria patients treated with IVQ in the ICU, $28.5 \%$ of them required red blood cell transfusion for marked anaemia [84]. Until further data are available, patients should be monitored for four weeks following IVA for haemolysis and leukopaenia. IVA should be completed with a full course of ACT, atovaquone/proguanil or mefloquine.

IVA produced under European Good Manufacturing Practice (GMP) standards is not yet available. Nevertheless, in some European countries (particularly in France), IVA manufactured in China (Guilin Pharmaceuticals) has been approved by the National Drug Agency and is now available with a specific temporary authorization of use (see section: «unlicensed drugs » below).

\section{Intravenous quinine (IVQ)}

IVQ is the drug of choice if IVA is not immediately available. An ECG should be obtained before starting IVQ. Use of a loading dose is recommended to rapidly obtain a therapeutic serum quinine level [84]. The loading dose is $20 \mathrm{mg} / \mathrm{kg}$ quinine dihydrochloride in $10 \%$ glucose or $0.9 \%$ sodium chloride infused over 4 hours. Treatment is continued with $10 \mathrm{mg} / \mathrm{kg}$ quinine dihydrochloride by infusion over $4 \mathrm{~h}$ in $500 \mathrm{ml}$ of $5 \%$ glucose, every $8 \mathrm{~h}$ until parasitaemia is less than $1 \%$ and the patient can take oral medication. Any previous treatment with mefloquine or quinine and/or an increased corrected QT interval $>25 \%$, are contra-indications for a loading dose because of an increased risk of cardiotoxicity. Continuous monitoring of the cardiac rhythm is necessary. The only strict contra-indications to IVQ are a documented previous history of blackwater fever [93], hypersensitivity to quinine, and cardiac arrythmia. Blackwater fever may occur on quinine treatment [93].

A full seven day course of IVQ is rarely completed. Quinine treatment can be changed either to an ACT or to an oral quinine-antibiotic combination as soon as the parasite density decreases and the patient tolerates oral treatment. The same principles apply for intravenous artesunate, where treatment is switched to oral ACT as soon as the parasite density has fallen adequately. In adults, doxycycline (or clindamycin during pregnancy) should be used in association with quinine if the quinine course cannot be followed by a course of ACT. Mefloquine should be avoided in patients with cerebral malaria even in the recovery phase. IVQ should be completed with a full course of $\mathrm{ACT}$, atovaquone/proguanil or mefloquine.

\section{Supportive care on ICU (Intensive Care Unit)}

Amongst the various scoring systems for adult malaria patients requiring ICU treatment outside endemic areas, SAPS II and the WHO score appear to be most reliable $[46,84,94]$. Fluid management is very important. Fluid overload may cause pulmonary oedema [95]. The intravascular volume should be high enough to ensure sufficient systemic perfusion, but overhydration has to be avoided, and adults with severe malaria are very vulnerable to fluid overload [79]. Monitoring of plasma lactate is mandatory. For children, the FEAST trial provided high quality evidence that during paediatric malaria fluid bolus significantly increases mortality [96]. The maintenance of a particular central venous pressure in severe malaria cannot be supported by available studies [97]. In adults with severe $P$. falciparum malaria there was no 
observed improvement in patient outcome or acid-base status with fluid loading. Neither CVP (Central venous Pressure) nor PAoP (Pulmonary Artery occlusion Pressure) correlated with markers of end-organ perfusion or respiratory status [98]. In the shocked and/or acidotic patient with severe malaria, bacterial co-infection should be sought by blood culture and antibiotic treatment started urgently [94,99].

Acute renal impairment and failure is frequent and indications for acute dialysis do not differ from acute renal failure in other conditions. Hyponatraemia is often seen in falciparum malaria, caused by reduced kidney function and consecutive dilutional hyponatraemia or by an Anti Diuretic Hormone Syndrome in the case of euvolemia. In both cases, treatment is by fluid restriction. Precise monitoring of the fluid balance is essential.

In the case of cerebral malaria the usual supportive measures practiced in neurological intensive care medicine are recommended. However, corticosteroids as well as mannitol should not be given, as they lead to prolongation of coma time and worsen the prognosis [79]. Hypoglycaemia is often seen, especially with quinine therapy and the blood sugar has to be monitored closely. Mefloquine should be avoided in patients with cerebral malaria even in the recovery phase because of the risk of post-malaria neurological syndrome.

There is no consensus on the indications, benefits and dangers involved in exchange blood transfusion, so it should not be used [79]. Automated red blood cell exchange (i.e. erythrocytopheresis) is another potentially useful adjunctive treatment option to rapidly reduce high parasitaemia by removing infected erythrocytes. It has the advantage of less interference with volume and electrolyte status of the patient, but no randomized controlled trial has been conducted so far $[100,101]$ and its role is unclear since the advent of ACT.

\section{Unlicensed drugs}

WHO guidelines recommend IVA in preference to quinine for the treatment of severe malaria in adults [80]. At present, no GMP (Good Manufacturing Practice) produced IVA is available in Europe. However, Guilin Pharmaceutical Factory No. 2 (Shanghai, People's Republic of China), the manufacturer of the artesunate used in major trials in Southeast Asia and Africa [87,88], may supply the drugs upon request. Artesunate manufactured by Guilin has received pre-qualification from the WHO.

Since 2011, the French National Health Agency (AFSSAPS), now named (ANSM) has temporarily authorized the import and use of IVA (Malacef ${ }^{\circledR}$ ) via ACR-Pharmaceuticals, the Netherlands, granting it a temporary authorization of use [102]. However, the use of non GMP artesunate remains sensitive from a legal point of view in many European countries, and some centres have addressed this by using a combination of quinine and artesunate, with satisfactory clinical outcomes and no safety concerns in a limited series of patients [103].

\section{Paediatric malaria}

Paediatric dosages are provided in Table 5. For imported cases, the risk of developing severe malaria is very high in VFR children without acquired semi-immunity and who are often more exposed to malaria [104]. Migrants' children are less likely to complain of chills, arthralgia/ myalgia or headaches. The clinical approach to the treatment of children is comparable to adult patients and relies on the classification into uncomplicated and severe falciparum malaria (Table 2). The clinical assessment of young children may be more challenging in particular when assessing potential alteration of mental status. Prostration - the inability to walk, stand, sit, or feed - is a useful clinical indicator for severe disease in endemic regions, and it may be a particularly useful clinical indicator for very young children.

In line with recommendations for adults, ACT and atovaquone-proguanil are the recommended first-line treatments for uncomplicated $P$. falciparum malaria in paediatric patients in Europe (Table 5). Paediatric formulations should be used if available [105].

Quinine-clindamycin or mefloquine mono-therapy (except for regions with multi-drug resistant $P$. falciparum strains such as the Thai-Myanmar-Cambodia region) are appropriate second line drugs. Tetracyclines are contra-indicated in children below 8 years of age (below 13 years in some countries).

The administration of drugs in general and the intensely bitter taste of anti-malarials in particular (even more so if adult tablets are crushed to improve the ease of administration) is an important concern in young children. The use of paediatric drug formulations has been shown to improve the tolerability of antimalarials. To date, artemether/lumefantrine and dihydroartemisinin/ piperaquine are useful first line paediatric antimalarials. Artmether/lumefantrine is available as a dispersible tablet formulation (registered in Switzerland only). Atovaquone/proguanil is also available as paediatric tablets. Anti-malarial treatment of severe malaria in children follows similar algorithms as for adult patients and is based on prompt administration of intravenous artesunate (or quinine if artesunate is not available). Children presenting with malaria are likely to have high fever which increases the risk of vomiting and seizures. Fever should be reduced by tepid sponging and the use of an anti-pyretic such as paracetamol. which can be administered rectally, though paracetamol prolongs parasite clearance times in children. 
Bacterial infections including sepsis and meningitis are more common in paediatric patients compared to adults in malaria endemic regions, and blood culture should be obtained on admission. Invasive non-typhoidal salmonella infections are among the most common invasive bacterial pathogens in some regions of Africa where malaria is highly endemic [106].

Congenital transmission of malaria to the newborn is a rare event and is estimated to occur in only $1 \%$ of newborns delivered by mothers with malaria. Clinical disease in the infant usually develops $2-8$ weeks postpartum and includes non-specific symptoms such as fever, vomiting, diarrhoea, and poor feeding. To date, little information is available for the appropriate treatment of cases of congenital malaria and in patients of less than $5 \mathrm{~kg}$ bodyweight. Therefore, weight adjusted treatment with artemether/lumefantrine, dihydroartemisinin/piperaquine and atovaquone/proguanil may be considered for this indication.

\section{Pregnant women}

Pregnant women are at increased risk for malaria related morbidity and mortality. This increased risk extends to the post-partum period [107]. Pregnant women presenting with acute malaria require prompt and effective treatment. Malaria in pregnancy is no indication for

Table 5 Paediatric Patients

\begin{tabular}{|c|c|c|}
\hline Drug & Dosage & Comment \\
\hline \multirow{5}{*}{$\begin{array}{l}\text { Artemether/Lumefantrine } \\
\left.\text { (Riamet }^{T M} \text {, Riamet Dispersible }{ }^{T M}\right) \\
(20 / 120 \mathrm{mg})\end{array}$} & 5-14 kg: 1 tablet per dose & $\begin{array}{l}\text { Registered for treatment of patients of } \geq 5 \mathrm{~kg} \\
\text { body weight }\end{array}$ \\
\hline & 15-24 kg: 2 tablets per dose & \multirow{4}{*}{$\begin{array}{l}\text { Dispersible drug formulation is registered } \\
\text { in Switzerland }\end{array}$} \\
\hline & 25-34 kg: 3 tablets per dose & \\
\hline & > 35 kg: 4 tablets per dose & \\
\hline & for 6 doses $(0-8-24-36-48-60 h)^{4}$ & \\
\hline \multirow{6}{*}{$\begin{array}{l}\text { Dihydroartemisinin/Piperaquine } \\
\left(\text { Eurartesim }^{\mathrm{TM}}\right)^{\circ}\end{array}$} & $5-<7 \mathrm{~kg}: 1 / 2$ tablet $160 \mathrm{mg} / 20 \mathrm{mg}$ & \multirow{2}{*}{$\begin{array}{l}\text { Registered for treatment of patients of } \geq 5 \mathrm{~kg} \\
\text { body weight }\end{array}$} \\
\hline & $7-<13 \mathrm{~kg} 1$ tablet $160 \mathrm{mg} / 20 \mathrm{mg}$ & \\
\hline & $13-<24 \mathrm{~kg}: 1$ tablet $320 \mathrm{mg} / 40 \mathrm{mg}$ & \multirow{4}{*}{$\begin{array}{l}\text { No paediatric drug formulation, but two strengths } \\
\text { of tablets make use of this ACT feasible in children }\end{array}$} \\
\hline & $24-<36 \mathrm{~kg}: 2$ tablets $320 \mathrm{mg} / 20 \mathrm{mg}$ & \\
\hline & $36-<75 \mathrm{~kg}: 3$ tablets $320 \mathrm{mg} / 40 \mathrm{mg}$ & \\
\hline & $\begin{array}{l}75-100 \mathrm{~kg}: 4 \text { tablets } 320 \mathrm{mg} / 40 \mathrm{mg} \text { once } \\
\text { daily for three days }\end{array}$ & \\
\hline \multirow{6}{*}{$\begin{array}{l}\text { Atovaquone/Proguanil } \\
\text { (Malarone }^{\mathrm{T} M}, \text { Malarone Paediatri } \mathrm{C}^{\mathrm{TM}} \text { ) }\end{array}$} & 5-8 kg: 2 tablets Malarone Paediatric & \multirow{6}{*}{$\begin{array}{l}\text { Registered for treatment of patients with }>5 \mathrm{~kg} \\
\text { body weight }\end{array}$} \\
\hline & 9-10 kg: 3 tablets Malarone Paediatric & \\
\hline & 11-20 kg: 1 tablet Malarone & \\
\hline & 21-30 kg: 2 tablets Malarone & \\
\hline & 31-40 kg: 3 tablets Malarone & \\
\hline & $\begin{array}{l}>40 \mathrm{~kg} \mathrm{KG:} 4 \text { tablets Malaroneonce daily } \\
\text { for three days }\end{array}$ & \\
\hline \multirow[t]{2}{*}{ Quinine*/Doxycycline } & \multirow{2}{*}{$\begin{array}{l}\text { Contraindicated in children below } 8 \text { years } \\
\text { of age ( } 13 \text { years in some countries) }\end{array}$} & No drug registration \\
\hline & & Loose drug combination \\
\hline \multirow[t]{2}{*}{ Quinine*/Clindamycin } & \multirow{2}{*}{$\begin{array}{l}\text { Thrice daily } 10 \mathrm{mg} / \mathrm{kg} \text { quinine plus twice } \\
\text { daily } 10 \mathrm{mg} / \mathrm{kg} \text { clindamycin for } 7 \text { days }\end{array}$} & No drug registration \\
\hline & & Loose drug combination \\
\hline \multirow[t]{7}{*}{ Mefloquine (LariamM) } & $5-10 \mathrm{~kg}: 1 / 2-1$ tablet & \multirow{7}{*}{$\begin{array}{l}\text { Registered for treatment of patients of } \geq 5 \mathrm{~kg} \\
\text { body weight }\end{array}$} \\
\hline & 10-20 kg: 1-2 tablets & \\
\hline & 20-30 kg: $2-3$ tablets $(2+1)$ & \\
\hline & 30-45 kg: 3-4 tablets $(2+2)$ & \\
\hline & 45-60 kg: 5 tablets $(3+2)$ & \\
\hline & $>60 \mathrm{~kg} 6$ tablets $(3+2+1)$ & \\
\hline & $\begin{array}{l}20-25 \mathrm{mg} / \mathrm{kg} \text { total dose divided in } 1-3 \text { doses } \\
6 \text { hours apart }\end{array}$ & \\
\hline
\end{tabular}

${ }^{*}$ Quinine dose provided as quinine sulphate.

${ }^{\circ}$ Eurartesim tablet strengths are Dihydroartemisinin/piperaquine $20 \mathrm{mg} / 160 \mathrm{mg}$ (children) and Dihydroartemisinin/piperaquine $40 \mathrm{mg} / 320 \mathrm{mg}$ (adults). 
Table 6 Malaria treatment in pregnancy

\begin{tabular}{|c|c|c|}
\hline \multicolumn{3}{|c|}{ Uncomplicated falciparum malaria } \\
\hline $1^{\text {st }}$ trimester $(1)$ & First line & Quinine-clindamycin quinine monotherapy \\
\hline \multirow[t]{2}{*}{$2^{\text {nd }}$ and $3^{\text {rd }}$ trimester } & First line & artemether-lumefantrine \\
\hline & Second line & quinine-clindamycin quinine monotherapy mefloquine (2) \\
\hline \multicolumn{3}{|c|}{ Complicated falciparum malaria } \\
\hline $1^{\text {st }}$ trimester & First line & i.v. quinine (+ follow on treatment) \\
\hline \multirow[t]{2}{*}{$2^{\text {nd }}$ and $3^{\text {rd }}$ trimester } & First line & i.v. artesunate (+ follow on treatment) \\
\hline & Second line & i.v. quinine (+ follow on treatment) \\
\hline \multicolumn{3}{|c|}{ P. ovale, P. malariae and P. vivax (3) } \\
\hline All trimesters & First line & Oral chloroquine \\
\hline $2^{\text {nd }}$ and $3^{\text {rd }}$ trimester & Second line & Oral ACT \\
\hline
\end{tabular}

1. Artemether/lumefantrine is not the first drug of choice due to lack of data on lumefantrine in pregnancy, but should be used if quinine is not available.

2. http://www.cdc.gov/malaria/new_info/2011/mefloquine_pregnancy.html.

3. Primaquine should not be used because of the risk of foetal haemolytic anaemia.

caesarean section due to the low risk for vertical transmission. Suggested treatment for uncomplicated malaria in pregnant women is shown on Table 6 . In complicated malaria, effective treatment with artesunate should be used to save the life of the mother even if there are safety concerns regarding the drug used. Quinine, chloroquine, clindamycin and proguanil are considered safe in the first trimester (Table 6). A recent database analysis of women exposed to mefloquine around the time of conception and in the first trimester showed no increased risk of malformations in offspring born to women who were exposed to mefloquine. Most of the women were exposed to chemoprophylactic doses rather than treatment doses of mefloquine [108].

Pregnant women presenting with malaria in the first trimester should be treated with quinine and clindamycin for 7 days. Artesunate and clindamycin for seven days can be used if there is treatment failure with the quinine/ clindamycin combination [80] (Table 6). Currently there is inadequate data on the use of ACT in the first trimester. Published data on 123 women exposed to ACT treatment in the first trimester showed no adverse outcomes. More data are available on ACT use in the second and third trimester (over 1,500 documented reports) and the WHO guidelines suggest that ACT should be used. Currently, there is insufficient evidence (154 cases) to recommend dihydroartesmisinin/piperaquine in pregnancy [109], so that artemether/lumefantrine is the only viable ACT option in Europe. Alternatives to artemether/lumefantrine in the second and third trimesters are quinine plus clindamycin or artesunate plus clindamycin [110] for 7 days in each case, or mefloquine monotherapy for regions without multidrug resistant parasites. Primaquine and tetracyclines should not be used in pregnancy. Atovaquone/proguanil is not recommended in pregnancy due to lack of data, but can be used in situations where no other drugs are available.
Treatment of $P$. vivax, $P$. ovale, $P$. malariae and $P$. knowlesi Plasmodium ovale and $P$. malariae generally remain sensitive to chloroquine in all endemic areas, despite reports of delayed parasite clearance time [111]. Plasmodium vivax sensitivity to chloroquine has declined steadily in Indonesia, Peru and Oceania [79] and a paradigm shift is imminent, with opinion leaders beginning to call for a switch to ACT as the drug of choice in Indonesia, Peru and Oceania. The use of artemether/lumefantrine has been suggested as a pragmatic choice in areas with chloroquine-resistant $P$. vivax [112] and it may also be used in mixed infections of $P$. falciparum with this parasite or with $P$. ovale or P. malariae [113]. Mefloquine (15 mg/kg body weight as a single dose) has been found to be highly effective against P.vivax with a treatment success of $100 \%$ [114]. Monotherapy with doxycycline (100 mg twice a day for 7 days) results in poor cure rates against $P$. vivax [115]. Monotherapy with artemisinins alone should not be used, except for intravenous artesunate therapy in the initial stages of treatment for severe infection. Quinine is also effective against chloroquine resistant $P$. vivax, but it is not an ideal treatment because of low tolerability and it may lead to early relapses [114]. First-line treatment is chloroquine with $\mathrm{ACT}$ as second line if the response to chloroquine is poor.

Plasmodium vivax and $P$. ovale infections, but not $P$. malariae, require treatment with primaquine $(\mathrm{PQ})$ for 14 days to eradicate liver hypnozoites and thus prevent relapses. Plasmodium vivax strains with reduced susceptibility to primaquine are found in southern regions of Oceania and South-East Asia and require a higher dose of primaquine (up to $0.75 \mathrm{mg}$ / $\mathrm{kg} /$ day, max $30 \mathrm{mg}$ per day) for 14 days to prevent relapses [116]. The CDC recommend routine use of $30 \mathrm{mg}$ per day in adults tested negative for G6PD deficiency [117], and this should be standard treatment 
for adult patients with $P$. vivax and $P$. ovale after G6PD testing according to the CDC [117]. Other centres use the higher dose only for P. vivax. Primaquine should be administered concomitantly with the blood schizonticide or as soon as possible after treatment.

Primaquine is contraindicated in patients with deficiency of the enzyme glucose-6-phosphate dehydrogenase [118]. In patients with mild G6PD deficiency the WHO suggests using an intermittent primaquine regimen of $0.75 \mathrm{mg}$ base $/ \mathrm{kg}$ once a week for eight weeks $[79,119]$. Patients with significant G6PD deficiency should be referred for expert advice. A study of primaquine $0.5 \mathrm{mg} / \mathrm{kg} /$ day in children where G6PD deficiency was excluded found good tolerability [120].

Treatment of $P$. knowlesi, a well-know primate malaria species that has recently recognized as causing a significant number of human malaria cases in South-East Asia and especially Malaysian Borneo, is not standardized, and WHO has not yet provided recommendations [79]. Evidence is fast accumulating that, like P.falciparum, $P$. knowlesi may cause severe cases, with fatality rates as high as $27 \%$, especially in older or female patients. Uncomplicated $P$. knowlesi cases can be treated with ACT, chloroquine, quinine, or atovaquone/proguanil [121]. Mefloquine may not be recommended in the light of case reports of treatment failure. There is no clear evidence of latent liver stages in P. knowlesi, and they have not been described in animal models [122,123]. A recent study showed that ACT cleared parasites faster than comparator antimalarials. In severe $P$. knowlesi cases, the use of IVA was associated with a lower case-fatality rate (17\% vs $31 \%$ ) and lower median parasite clearance time (2 days vs 4 days) than IVQ [124]. Thus uncomplicated
P. knowlesi should be treated with chloroquine or an ACT drug and complicated P. knowlesi with IVA.

\section{Interactions}

The effect of food on the absorption and pharmacokinetics of anti-malarials is important (Table 3). In general, orally administered agents are given with food to enhance absorption. The exception is dihydroartemisinin/ piperaquine which should be administered fasting, as studies have shown that this reduces the possible QTc prolongation impact of piperaquine [Eurartesim - EMA summary of Product Characteristics]. Conversely, for artemether/lumefantrine a fatty meal is recommended to achieve therapeutic levels of the fat soluble lumefantrine.

The most prominent drug/drug interaction is the effect on QTc-prolongation with quinine, artemether/ lumefantrine as well as with mefloquine. The effect of the individual drugs can be enhanced if they are used together, consecutively, or at the same time as other cardioactive drugs, such as ketoconazole or phenothiazines. Quinine and atovaquone/proguanil can enhance the effect of anticoagulants. Concomitant treatment with rifampicin, metoclopramide or tetracycline can result in a lower plasma concentration of atovaquone/proguanil.

Treatment of HIV/malaria co-infected patients has potential for drug interactions (Table 7). A recent paper examining the co-administration of artemether/ lumefantrine with lopinavir/ritonavir, showed significant increases in lumefantrine blood levels but decreases in artemether blood levels [125]. Further studies are needed to assess the clinical importance of antiretroviral antimalarial drug interactions.

Table 7 Drug interactions between antimalarial and antiretroviral medication

\begin{tabular}{|c|c|c|c|c|c|c|}
\hline Drugs & Mefloquine & Atovaquone & Proguanil & Chloroquine & Artemisinins & Quinine \\
\hline \multicolumn{7}{|l|}{ Protease inhibitors } \\
\hline Saquinavir & - & + & - & - & $?$ & + \\
\hline Ritonavir & - & + & + & + & + & + \\
\hline Indinavir & - & + & - & - & $?$ & + \\
\hline Nelfinavir & - & + & - & - & $?$ & + \\
\hline Amprenavir & - & + & - & - & $?$ & + \\
\hline Lopinavir & - & + & - & - & + & + \\
\hline Atazanavir & - & + & - & - & $?$ & + \\
\hline \multicolumn{7}{|l|}{ NNRTIs ${ }^{(1)}$} \\
\hline Nevirapine, efavirenz and others & - & - & - & - & $?$ & + \\
\hline \multicolumn{7}{|l|}{ NRTIs ${ }^{(2)}$} \\
\hline Zidovudine and others & - & - & - & - & - & - \\
\hline
\end{tabular}

(1) Non-Nucleoside Reverse Transcriptase Inhibitors.

(2) Nucleoside Reverse Transcriptase Inhibitors.

-No clinically significant interaction, or interaction unlikely based on knowledge of drug metabolism.

+Potential interaction that may require dose monitoring, alteration of drug dosage or timing of administration. 
Table 8 Recommendations

When should malaria be suspected?

Initial diagnosis

Monitoring after diagnosis

Treatment of uncomplicated malaria

Treatment of complicated malaria

Treatment of non-falciparum malaria

Managing uncomplicated malaria

Managing complicated malaria
In all ill patients with a travel history of visiting amalaria endemic area in the last year, especially inthe last 3 months.

Microscopy of thick and thin Giemsa stained bloodfilms. Use of a rapid diagnostic test can be used ifmicroscopy is unavailable initially, but follow upby microscopy is essential.

Microscopy of thick and thin Giemsa stained bloodfilms. If this skill is not available the patient shouldbe transferred to a level where microscopy can be performed.

See tables 1 and 2. Artemisinin combination therapy or atovaquone-proguanil are first linetreatment options for P.falciparum and can also be used for the other species. Chloroquine is the first line treatment for other malaria species.

Artesunate or quinine intravenously. If available,artesunate is preferable to quinine. These drugs must be available at the health care facility managing patients with malaria.

Chloroquine is the drug of choice and ACT a pragmatic alternative. In case of chloroquine resistance an $A C T$ is second line treatment.

Primaquine is given after testing for G6PD at adose of $30 \mathrm{mg}$ per day for patients infected in Southeast Asia; otherwise 15 mg/day.

Patients with $P$. falciparum malaria should preferably be managed as in-patients. Under certain circumstances out-patient management may be acceptable provided there are daily assessments and daily blood films for parasitaemia until clinical and parasitological cure.

Patients with complicated $P$. falciparum malaria (Table4) should be managed as inpatients in anIntensive Care Unit.

Patients receiving intravenous artesunate should be monitored twice weekly for 4 weeks following IVA for hemolysis and leucopenia.

\section{Conclusions}

All hospitals in Europe should have plans for diagnosing and managing patients with malaria. Obtaining a travel history is mandatory for all patients with fever. If RDTs indicate the diagnosis of malaria but microscopy cannot be performed adequate treatment should be started straight away and the patient promptly transferred to a health care facility where microscopy can be done. In the case of a negative RDT but high suspicion of malaria, patients should also be transferred to a centre with expertise in the microscopic diagnosis of malaria. ACT should be available for treatment of uncomplicated malaria and intravenous artesunate available for severe or complicated malaria. Intravenous quinine should be available if it is not possible to maintain a stock of intravenous artesunate.

A standing committee is proposed to harmonize guidelines as far as possible, whilst recognizing the need in some areas for individual/country-specific decisionmaking. The main recommendations for non-specialist physicians are summarized on Table 8.

\section{Competing interests}

Gerd Burchard has received speakers' honoraria from GlaxoSmithKline, Novartis Pharma and Sigma-Tau. Peter L. Chiodini has received speakers' honoraria from GlaxoSmithKline. Patricia Schlagenhauf has received speakers' honoraria and research funds from GlaxoSmithKline, speakers honoraria, research funds and consultancy fees from F. Hoffmann-La Roche and she is a member of the sigma-tau advisory board. Eskild Petersen has received speakers a honoraria from GlaxoSmithKline.

\section{Authors' contributions}

EP coordinated the project and manuscript, all authors contributed sections to the manuscript and all authors read and approved the final manuscript.

\section{Acknowledgement}

PLC is supported by the UCL Hospitals Comprehensive Biomedical Research Centre Infection Theme. We are grateful to Sanjeev Krishna, St George's Hospital Medical School, University of London, for comments and suggestions.

\section{Author details}

${ }^{1}$ Department of Medicine Solna/Unit for Infectious Diseases, Karolinska Institutet, Stockholm, Sweden. ${ }^{2}$ Department of Communicable Disease Control and Prevention, Stockholm County Council, Stockholm, Sweden. ${ }^{3}$ Intensive Care Unit, Centre Hospitalier de Versailles, Site André Mignot, 177 rue de Versailles, Le Chesnay 78150, France. ${ }^{4}$ Bernhard-Nocht-Institut für Tropenmedizin, Hamburg, Germany. ${ }^{5}$ University Division of Infectious and Tropical Diseases, University of Brescia and Spedali Civili General Hospital, Brescia, Italy. ${ }^{6}$ Hospital for Tropical Diseases and London School of Hygiene and Tropical Medicine, London, UK. ${ }^{7}$ Center for Tropical Medicine and Travel Medicine, Department of Infectious Diseases, Academic Medical Center, University of Amsterdam, Amsterdam, The Netherlands. ${ }^{8}$ Tropical Medicine \& Clinical Parasitology. Infectious Diseases Department.Hospital Ramón y Cajal, Madrid, Spain. ${ }^{9}$ Department and Clinic of Tropical and Parasitic Diseases, University of Medical Sciences, Poznan, Poland. ${ }^{10}$ Department of Infectious Diseases, Aarhus University Hospital Skejby, Aarhus, Denmark. ${ }^{11} \mathrm{Clinical}$ Hospital of Infectious and Tropical Diseases "Dr.Victor Babes", University of Medicine and Pharmacy "Carol Davila" Bucharest, Bucharest, Romania. ${ }^{12}$ Department. of Medicine I, Div. of Infectious Diseases and Tropical Medicine, Medical University of Vienna, Vienna, Austria. ${ }^{13}$ University of Zürich, Centre for Travel Medicine, Division of Epidemiology and Communicable Diseases, Zürich, Switzerland.

Received: 29 June 2012 Accepted: 19 August 2012

Published: 17 September 2012

\section{References}

1. Grobusch MP, Kremsner PG: Uncomplicated malaria. Curr Topics Microbiol Immunol 2005, 295:83-104.

2. Bouchaud O, Mühlberger N, Parola P, Calleri G, Matteelli A, Peyerl-Hoffmann G, Méchai F, Gautret P, Clerinx J, Kremsner PG, Jelinek T, Kaiser A, Beltrame A, Schmid M, Kern P, Probst M, Bartoloni A, Weinke T, Grobusch MP: Therapy of uncomplicated falciparum malaria in 
Europe - a prospective observational multicentre study. Malar J 2012, 11:212.

3. Cibulskis RE, Aregawi M, Williams R, Otten M, Dye C: Worldwide incidence of malaria in 2009: estimates, time trends, and a critique of methods. PLoS Med 2011, 8:e1001142.

4. Murray CJ, Rosenfeld LC, Lim SS, Andrews KG, Foreman KJ, Haring D, Fullman N, Naghavi M, Lozano R, Lopez AD: Global malaria mortality between 1980 and 2010: a systematic analysis. Lancet 2012, 379:413-431.

5. World Health Organization: World Malaria Report 2011. Geneva: WHO; 2011. http://www.who.int/malaria/world_malaria_report_2011/en/) (Accesses $27^{\text {th }}$ May 2012).

6. World Health Organization Regional Office for Europe: Centralized information system for infectious dieases (CISID). 2012. Available at: http://data.euro.who.int/cisid (Accessed 27th May 2012).

7. Checkley AM, Smith A, Smith V, Blaze M, Bradley D, Chiodini PL, Whitty CJ: Risk factors for mortality from imported falciparum malaria in the United Kingdom over 20 years: an observational study. BMJ 2012, 344:e2116.

8. Odolini S, Parola P, Gkrania-Klotsas E, Caumes E, Schlagenhauf P, López-Vélez R, Burchard GD, Santos-O'Connor F, Weld L, von Sonnenburg F, Field V, de Vries P, Jensenius M, Loutan L, Castelli F: Travel-related imported infections in Europe, EuroTravNet 2009. Clin Microbiol Infect 2011, 18:468-474.

9. Mali S, Kachur SP, Arguin PM, Division of Parasitic Diseases and Malaria, Center for Global Health: Centers for Disease Control and Prevention (CDC): Malaria surveillance--United States, 2010. MMWR Surveill Summ 2012, 61:1-17.

10. Seringe $E$, Thellier M, Fontanet A, Legros F, Bouchaud O, Ancelle T, Kendjo E, Houze S, Le Bras J, Danis M, Durand R: French National Reference Center for Imported Malaria Study Group: Severe imported Plasmodium falciparum malaria, France, 1996-2003. Emerg Infect Dis 2011, 17:807-813.

11. Jelinek T, Larsen CS, Siikamäki H, Myrvang B, Chiodini P, Gascon J: European cluster of imported falciparum malaria from Gambia. Euro Surveill 2008, 13:pii:19077.

12. Sabatinelli G, Ejov M, Joergensen P: Malaria in the WHO European Region (1971-1999). Euro Surveill 2001, 6:61-65.

13. Askling HH, Nilsson J, Tegnell A, Janzon R, Ekdahl K: Malaria risk in travelers. Emerg Infect Dis 2005, 11:436-441.

14. European Commission. Eurostat. Katya Vasileva: Population and social conditions. 2011. 4/2011. Available at: http://epp.eurostat.ec.europa.eu/ cache/ITY OFFPUB/KS-SF-11-034/EN/KS-SF-11-034-EN.PDF.

15. Jelinek T, Schulte C, Behrens R, Grobusch MP, Coulaud JP, Bisoffi Z, Matteelli A, Clerinx J, Corachán M, Puente S, Gjørup I, Harms G, Kollaritsch H, Kotlowski A, Björkmann A, Delmont JP, Knobloch J, Nielsen LN, Cuadros J, Hatz C, Beran J, Schmid ML, Schulze M, Lopez-Velez R, Fleischer K, Kapaun A, McWhinney P, Kern P, Atougia J, Fry G, da Cunha S, Boecken G: Imported Falciparum malaria in Europe: sentinel surveillance data from the European network on surveillance of imported infectious diseases. Clin Infect Dis 2002, 34:572-576.

16. Develoux M, Le Loup G, Dautheville S, Belkadi G, Magne D, Lassel L, Bonnard P, Pialoux G: [Malaria among immigrants, experience of a Parisian hospital (2006-2010)] (in French). Bull Soc Pathol Exot 2012, 105:95-102.

17. Romi R, Sabatinelli G, Majori G: Malaria epidemiological situation in Italy and evaluation of malaria incidence in Italian travelers. J Travel Med 2001, 8:6-11.

18. Mascarello M, Gobbi F, Angheben A, Concia E, Marocco S, Anselmi M, Monteiro G, Rossanese A, Bisoffi Z: Imported malaria in immigrants to Italy: a changing pattern observed in north eastern Italy. J Travel Med 2009, 16:317-321.

19. Leder K, Tong S, Weld L, Kain KC, Wilder-Smith A, von Sonnenburg F, Black J, Brown GV, Torresi J, GeoSentinel Surveillance Network: Illness in travelers visiting friends and relatives: a review of the GeoSentinel Surveillance Network. Clin Infect Dis 2006, 43:1185-1193.

20. Stäger K, Legros F, Krause G, Low N, Bradley D, Desai M, Graf S, D'Amato S, Mizuno $Y$, Janzon R, Petersen $E$, Kester J, Steffen $R$, Schlagenhauf $P$ : Imported malaria in children in industrialized countries, 1992-2002. Emerg Infect Dis 2009, 15:185-191.

21. Danis K, Baka A, Lenglet A, Van Bortel W, Terzaki I, Tseroni M, Detsis M, Papanikolaou E, Balaska A, Gewehr S, Dougas G, Sideroglou T, Economopoulou A, Vakalis N, Tsiodras S, Bonovas S, Kremastinou J: Autochthonous Plasmodium vivax malaria in Greece, 2011. Euro Surveill 2011, 16:19993.

22. Bacaner N, Stauffer B, Boulware DR, Walker PF, Keystone JS: Travel medicine considerations for North American immigrants visiting friends and relatives. JAMA 2004, 291:2856-2864.

23. Scolari C, Tedoldi S, Casalini C, Scarcella C, Matteelli A, Casari S, El Hamad I, Castelli F: Knowledge, attitudes and practices on malaria preventive measures in migrants attending a public health clinic in northern Italy. J Trav Med 2002, 9:160-162.

24. Angell SY, Behrens RH: Risk assessment and disease prevention in travelers visiting friends and relatives. Infect Dis Clin North Am 2005, 19:49-65.

25. Fulford M, Keystone JS: Health risks associated with visiting friends and relatives in developing countries. Curr Infect Dis Rep 2005, 7:48-53.

26. Millet JP, Garcia De Olalla P, Carrillo-Santisteve P, Gascón J, Treviño B, Muñoz J, Gómez I Prat J, Cabezos J, González Cordón A, Caylà JA: Imported malaria in a cosmopolitan European city: a mirror image of the world epidemiological situation. Malar J 2008, 7:56.

27. Driessen GJ, Pereira RR, Brabin BJ, Hartwig NG: Imported malaria in children: a national surveillance in the Netherlands and a review of European studies. Eur J Public Health 2008, 18:184-188.

28. Pereira RR, Brabin BJ, Hartwig NG: Imported malaria in children: a national surveillance in the Netherlands and a review of European studies. Eur J Public Health 2008, 18:184-188.

29. Mascarello M, Allegranzi B, Angheben A, Anselmi M, Concia E, Laganà S, Manzoli L, Marocco S, Monteiro G, Bisoffi Z: Imported malaria in adults and children: epidemiological and clinical characteristics of 380 consecutive cases observed in Verona, Italy. J Travel Med 2008, 15:229-236.

30. Thang HD, Elsas RM, Veenstra J: Airport malaria: report of a case and a brief review of the literature. Neth J Med 2002, 60:441-443.

31. Tatem AJ, Rogers DJ, Hay SI: Estimating the malaria risk of African mosquito movement by air travel. Malar J 2006, 5:57.

32. Castelli F, Cabona MG, Brunori A, Carosi G: Imported mosquito: an uninvited guest. Am J Trop Med Hyg 1994, 50:548-549.

33. Chau TT, Mai NT, Phu NH, Luxemburger C, Chuong LV, Loc PP, Trang TT, Vinh H, Cuong BM, Waller DJ, Sinh DX, Day NP, Hien TT, White NJ: Malaria in injection drug abusers in Vietnam. Clin Infect Dis. 2002, 34:1317-1322.

34. Noubouossie D, Tagny CT, Same-Ekobo A, Mbanya D: Asymptomatic carriage of malaria parasites in blood donors in Yaoundé. Transfus Med 2012, 22:63-67.

35. Machado CM, Martins TC, Colturato I, Leite MS, Simione AJ, Souza MP, Mauad MA, Colturato VR: pidemiology of neglected tropical diseases in transplant recipients. Review of the literature and experience of a Brazilian HSCT center. Rev Inst Med Trop Sao Paulo 2009, 51:309-324.

36. Francischetti IM, Seydel KB, Monteiro RQ: Blood coagulation, inflammation, and malaria. Microcirculation 2008, 15:81-107.

37. White NJ: Cerebral perfusion in cerebral malaria. Crit Care Med 1999, 27:478-479.

38. Sherman IW, Eda S, Winograd E: Cytoadherence and sequestration in Plasmodium falciparum: defining the ties that bind. Microbes Infect 2003, 5:897-909.

39. Dondorp AM, Kager PA, Vreeken J, White NJ: Abnormal blood flow and red blood cell deformability in severe malaria. Parasito/ Today 2000, 16:228-232.

40. Pain A, Urban BC, Kai O, Casals-Pascual C, Shafi J, Marsh K, Roberts DJ: A non-sense mutation in $\mathrm{Cd} 36$ gene is associated with protection from severe malaria. Lancet 2001, 357:1502-1503.

41. Chotivanich K, Sritabal J, Udomsangpetch R, Newton P, Stepniewska KA, Ruangveerayuth R, Looareesuwan S, Roberts DJ, White NJ: Platelet-induced autoagglutination of Plasmodium falciparum-infected red blood cells and disease severity in Thailand. J Infect Dis 2004, 189:1052-1055.

42. MacPherson GG, Warrell MJ, White NJ, Looareesuwan S, Warrell DA: Human cerebral malaria. A quantitative ultrastructural analysis of parasitized erythrocyte sequestration. Am J Pathol 1985, 119:385-401.

43. Prommano $O$, Chaisri U, Turner GD, Wilairatana P, Ferguson DJ, Viriyavejakul $P$, White NJ, Pongponratn E: A quantitative ultrastructural study of the liver and the spleen in fatal falciparum malaria. Southeast Asian J Trop Med Public Health 2005, 36:1359-1370.

44. Watt $G$, Jongsakul $K$, Ruangvirayuth $\mathrm{R}$ : A pilot study of $\mathrm{N}$-acetylcysteine as adjunctive therapy for severe malaria. QJM 2002, 95:285-290.

45. Planche T, Onanga M, Schwenk A, Dzeing A, Borrmann S, Faucher JF, Wright A, Bluck L, Ward L, Kombila M, Kremsner PG, Krishna S: Assessment of volume depletion in children with malaria. PLOS Med 2004, 1:56-63.

46. Santos LC, Abreu CF, Xerinda SM, Tavares M, Lucas R, Sarmento AC: Severe imported malaria in an intensive care unit: a review of 59 cases. Malar $J$ 2012, 11:96

47. Legros F, Bouchaud O, Ancelle T, Arnaud A, Cojean S, Le Bras J, Danis M, Fontanet A, Durand R, for the French National Reference Centers for Imported and Autochthonous Malaria Epidemiology and Chemosensitivity Network: Risk factors for imported fatal Plasmodium falciparum malaria, France, 1996-2003. Emerg Infect Dis 2007, 13:883-888. 
48. Muentener P, Schlagenhauf P, Steffen R: Imported malaria (1985-95): trends and perspectives. Bull World Health Organ 1999, 77:560-566

49. Wertheimer ER, Brundage JF, Fukuda MM: High rates of malaria among US military members born in malaria-endemic countries, 2002-2010. Emerg Infect Dis 2011, 17:1701-1703.

50. D'Ortenzio E, Godineau N, Fontanet A, Houze S, Bouchaud O, Matheron S, LeBras J: Prolonged Plasmodium falciparum infection in immigrants, Paris. Emerg Infect Dis 2008, 14:323-326.

51. Bouchaud O, Cot M, Kony S, Durand R, Schiemann R, Ralaimazava P: Do African immigrants living in France have long-term malarial immunity? Am J Trop Med Hyg 2005, 72:21-25.

52. Krajden S, Panisko DM, Tobe B, Yang J, Keystone JS: Prolonged infection with Plasmodium falciparum in a semi-immune patient. Trans $R$ Soc Trop Med Hyg 1991, 85:731-732.

53. Greenwood T, Vikerfors T, Sjoberg M, Skeppner G, Farnert A: Febrile Plasmodium falciparum malaria 4 years after exposure in a man with sickle cell disease. Clin Infect Dis 2008, 47:e39-e41.

54. Szmitko PE, Kohn ML, Simor AE: Plasmodium falciparum malaria occurring 8 years after leaving an endemic area. Diagn Microbiol Infect Dis 2009, 63:105-107.

55. Monge-Maillo $B$, Jiménez BC, Pérez-Molina JA, Norman F, Navarro M, Pérez-Ayala A, Herrero JM, Zamarrón P, López-Vélez R: Imported infectious diseases in mobile populations, Spain. Emerg Infect Dis 2009, 15:1745-1752.

56. Marangi M, Di Tullio R, Mens PF, Martinelli D, Fazio V, Angarano G, Schallig HD, Giangaspero A, Scotto G: Prevalence of Plasmodium spp. in malaria asymptomatic African migrants assessed by nucleic acid sequence based amplification. Malar J 2009, 8:12.

57. WHO. Geneva: International Travel and Health; 2012. http://www.who.int/ ith/en/ (Accessed 27 $7^{\text {th }}$ May 2012).

58. Hagmann S, Khanna K, Niazi M, Purswani M, Robins EB: Congenital malaria, an important differential diagnosis to consider when evaluating febrile infants of immigrant mothers. Pediatr Emerg Care 2007, 23:326-329.

59. Del Punta V, Gulletta M, Matteelli A, Spinoni V, Regazzoli A, Castelli F: Congenital Plasmodium vivax mimicking neonatal sepsis: a case report. Malar J 2010, 9:63.

60. Grobusch MP, Borrmann S, Omva J, Issifou S, Kremsner PG: Severe malaria in a splenectomised Gabonese woman. Wien Klin Wochenschr 2003, 115:63-65.

61. Ladhani S, Garbash M, Whitty CJ, Chiodini PL, Aibara RJ, Riordan FA, Shingadia D: Prospective, national clinical and epidemiologic study on imported childhood malaria in the United Kingdom and the Republic of Ireland. Pediatr Infect Dis J. 2010, 29:434-438.

62. van Wolfswinkel ME, Hesselink DA, Zietse R, Hoorn EJ, van Genderen PJJ: Hyponatraemia in imported malaria is common and associated with disease severity. Malar J 2010, 9:140.

63. Yeo TW, Lampah DA, Gitawati R, Tjitra E, Kenangalem E, McNeil YR, Darcy CJ, Granger DJ, Weinberg JB, Lopansri BK, Price RN, Duffull SB, Celermajer DS, Anstey NM: Recovery of endothelial function in severe falciparum malaria: relationship with improvement in plasma L-arginine and blood lactate concentrations. J Infect Dis 2008, 198:602-608.

64. Reddy EA, Shaw AV, Crump JA: Community-acquired bloodstream infections in Africa: a systematic review and meta-analysis. Lancet Infect Dis 2010, 10:417-432.

65. Cunnington AJ, de Souza JB, Walther M, Riley EM: Malaria impairs resistance to Salmonella through heme- and heme oxygenase-dependent dysfunctional granulocyte mobilization. Nat Med 2011, 18:120-127.

66. Bowers KM, Bell D, Chiodini PL, Barnwell J, Incardona S, Yen S, Luchavez J, Watt $\mathrm{H}$ : Inter-rater reliability of malaria parasite counts and comparison of methods. Malar J 2009, 8:267.

67. Petersen E, Marbiah NT, New L, Gottschau A: Comparison of two methods for enumerating malaria parasites in thick blood films. Am J Trop Med Hyg 1996, 55:485-489.

68. Flegg JA, Guerin PJ, White NJ, Stepniewska K: Standardizing the measurement of parasite clearance in falciparum malaria: the parasite clearance estimator. Malar J 2011, 10:339.

69. World Health Organization: Rapid Diagnostic Tests. Results of round 3. 2012 http://www.who.int/tdr/publications/tdr-research-publications/rdt_round3/ en/index.html Geneva 2011. (Accessed 27th May 2012).

70. Mahajan B, Zheng H, Pham PT, Sedegah MY, Majam VF, Akolkar N, Rios M, Ankrah I, Madjitey P, Amoah G, Addison E, Quakyi IA, Kumar S: Polymerase chain reaction-based tests for pan-species and species-specific detection of human Plasmodium parasites. Transfusion 2012, doi:10.1111/j.15372995.2011.03541.x [Epub ahead of print]

71. Luchavez J, Baker J, Alcantara S, Belizario V Jr, Cheng Q, McCarthy JS, Bell D: Laboratory demonstration of a prozone-like effect in HRP2-detecting malaria rapid diagnostic tests: implications for clinical management. Malar J 2011, 10:286.

72. Gillet $P$, Scheirlinck A, Stokx J, De Weggheleire A, Chaúque HS, Canhanga OD, Tadeu BT, Mosse CD, Tiago A, Mabunda S, Bruggeman C, Bottieau E, Jacobs J: Prozone in malaria rapid diagnostics tests: how many cases are missed? Malar J 2011, 10:166

73. Koita OA, Doumbo OK, Ouattara A, Tall LK, Konaré A, Diakité M, Diallo M, Sagara I, Masinde GL, Doumbo SN, Dolo A, Tounkara A, Traoré I, Krogstad $D J$ : False-negative rapid diagnostic tests for malaria and deletion of the histidine-rich repeat region of the hrp2 gene. Am J Trop Med Hyg 2012, 86:194-198.

74. Baker J, Gatton ML, Peters J, Ho MF, McCarthy JS, Cheng Q: Transcription and expression of Plasmodium falciparum histidine-rich proteins in different stages and strains: implications for rapid diagnostic tests. PLoS One 2011, 6:e22593.

75. Grobusch MP, Alpermann U, Schwenke S, Jelinek T, Warhurst DC: Falsepositive rapid tests for malaria in patients with rheumatoid factor. Lancet 1999, 353:297.

76. Chiodini PL, Bowers K, Jorgensen P, Barnwell JW, Grady KK, Luchavez J, Moody AH, Cenizal A, Bell D: The heat stability of Plasmodium lactate dehydrogenase-based and histidine-rich protein 2-based malaria rapid diagnostic tests. Trans R Soc Trop Med Hyg 2007, 101:331-337.

77. van Hellemond JJ, Rutten M, Koelewijn R, Zeeman AM, Verweij JJ, Wismans PJ, Kocken CH, van Genderen PJ: Human Plasmodium knowlesi infection detected by rapid diagnostic tests for malaria. Emerg Infect Dis 2009, 15:1478-1480.

78. World Health Organization: Severe falciparum malaria. Trans $R$ Soc Trop Med Hyg 2000, 94(Suppl 1):S1-90.

79. World Health Organization: Guidelines for the treatment of malaria. Geneva: WHO; 2011. http://www.who.int/malaria/world_malaria_report_2010/en/ index.html.

80. Wernsdorfer WH: Coartemether (artemether and lumefantrine): an oral antimalarial drug. Expert Rev Anti Infect Ther 2004, 2:181-96.

81. Weinke T, Trautmann M, Held T, Weber G, Eichenlaub D, Fleischer K, Kern W, Pohle HD: Neuropsychiatric side effects after the use of mefloquine. Am J Trop Med Hyg 1991, 45:86-91.

82. Adegnika AA, Breitling LP, Agnandji ST, Chai SK, Schütte D, Oyakhirome S, Schwarz NG, Grobusch MP, Missinou MA, Ramharter M, Issifou S, Kremsner PG: Effectiveness of quinine monotherapy for the treatment of Plasmodium falciparum infection in pregnant women in Lambaréné, Gabon. Am J Trop Med Hyg 2005, 73:263-266.

83. Franklin BS, Vitorino BL, Coelho HC, Menezes-Neto A, Santos ML, Campos FM, Brito CF, Fontes CJ, Lacerda MV, Carvalho LH: Plasma circulating nucleic acids levels increase according to the morbidity of Plasmodium vivax malaria. PLoS One 2011, 6:e19842.

84. de Langue Française SdPI, Tropicales CdUdMle, Armées SFdMd, de Parasitologie SF, de Pédiatrie SF, Voyages SdMd, de Pathologie Exotique S, de Langue Française SdR: Recommendations for clinical practice. Management and prevention of imported Plasmodium falciparum malaria. Med Mal Infect 2008, 38:54-67.

85. Société de Pathologie Infectieuse de Langue Française, Collège des Universitaires de Maladies Infectieuses et Tropicales, Société de Réanimation de Langue Française, et al.: Recommendations for clinical practice. Management and prevention of imported Plasmodium falciparum malaria. Med Mal Infect 2008, 38:54-67.

86. Sinclair D, Donegan S, Isba R, Lalloo DG: Artesunate versus quinine for treating severe malaria. The Cochrane Library 2012, doi:10.1002/14651858. CD005967.pub4

87. Dondorp A, Nosten F, Stepniewska K, Day N, White N: Artesunate versus quinine for treatment of severe falciparum malaria: a randomised trial. Lancet 2005, 366:717-725.

88. Dondorp AM, Fanello Cl, Hendriksen IC, Gomes E, Seni A, Chhaganlal KD, Bojang K, Olaosebikan R, Anunobi N, Maitland K, Kivaya E, Agbenyega T, Nguah SB, Evans J, Gesase S, Kahabuka C, Mtove G, Nadjm B, Deen J, MwangaAmumpaire J, Nansumba M, Karema C, Umulisa N, Uwimana A, Mokuolu OA, Adedoyin OT, Johnson WB, Tshefu AK, Onyamboko MA, Sakulthaew T, Ngum 
WP, Silamut K, Stepniewska K, Woodrow CJ, Bethell D, Wills B, Oneko M, Peto TE, von Seidlein L, Day NP: White NJ; AQUAMAT group: Artesunate versus quinine in the treatment of severe falciparum malaria in African children (AQUAMAT): an open-label, randomised trial. Lancet 2010, 376:1647-1657.

89. Cramer JP, Lopez-Velez R, Burchard GD, Grobusch MP, de Vries PJ: Treatment of imported severe malaria with artesunate instead of quinine - more evidence needed? Malar J 2011, 10:256

90. Zoller T, Junghanss T, Kapaun A, Gjorup I, Richter J, Hugo-Persson M, Mørch K, Foroutan B, Suttorp N, Yürek S, Flick H: Intravenous artesunate for severe malaria in travelers, Europe. Emerg Infect Dis 2011, 17:771-777.

91. Kreeftmeijer-Vegter AR, van Genderen PJ, Visser LG, Bierman WF, Clerinx J, van Veldhuizen CK, de Vries PJ: Treatment outcome of intravenous artesunate in patients with severe malaria in the Netherlands and Belgium. Malar J 2012, 11:102.

92. Rolling T, Schmiedel S, Wichmann D, Wittkopf D, Burchard GD, Cramer JP: Post-treatment haemolysis in severe imported malaria after intravenous artesunate: case report of three patients with hyperparasitaemia. Malar J 2012, 11:169.

93. Bruneel F, Gachot B, Wolff M, Régnier B, Danis M, Vachon F: Resurgence of blackwater fever in long-term European expatriates in Africa: report of 21 cases and review. Clin Infect Dis 2001, 32:1133-1140.

94. Bruneel F, Hocqueloux L, Alberti C, Wolff M, Chevret S, Bédos JP, Durand R, Le Bras J, Régnier B, Vachon F: The clinical spectrum of severe imported falciparum malaria in the intensive care unit: report of 188 cases in adults. Am J Respir Crit Care Med 2003, 167:684-689.

95. Losert H, Schmid K, Wilfing A, Winkler S, Staudinger T, Kletzmayr J, Burgmann $\mathrm{H}$ : Experiences with severe $P$. falciparum malaria in the intensive care unit. Intensive Care Med 2000, 26:195-201.

96. Maitland K, Kiguli S, Opoka RO, Engoru C, Olupot-Olupot P, Akech SO and the FEAST Trial Group: Mortality after fluid bolus in African children with severe infection. N Engl J Med 2011, 364:2483-2495.

97. Hanson J, Lam SW, Mohanty S, Alam S, Hasan MM, Lee SJ, Schultz MJ, Charunwatthana P, Cohen S, Kabir A, Mishra S, Day NP, White NJ, Dondorp AM: Central venous catheter use in severe malaria: time to reconsider the World Health Organization guidelines? Malar J 2011, 10:342.

98. Nguyen HP, Hanson J, Bethell D, Nguyen TH, Tran TH, Ly VC: A retrospective analysis of the haemodynamic and metabolic effects of fluid resuscitation in Vietnamese adults with severe falciparum malaria. PLoS One 2011, 6:e25523.

99. Bruneel F, Gachot B, Timsit JF, Wolff M, Bédos JP, Régnier B, Vachon F: Shock complicating severe falciparum malaria in European adults. Int Care Med 1997, 23:698-701.

100. Files JC, Case CJ, Morrison FS: Automated erythrocyte exchange in fulminant falciparum malaria. Ann Intern Med 1984, 100:396.

101. Auer-Hackenberg L, Staudinger T, Bojic A, Locker G, Leitner GC, Graninger W, Winkler S, Ramharter M, Worel N: Automated red blood cell exchange as an adjunctive treatment for severe Plasmodium falciparum malaria at the Vienna General Hospital in Austria: A retrospective cohort study. Malar J 2012, 11:158.

102. Bruneel F: Intravenous artesunate for the treatment of severe malaria. Réanimation 2012, 21:S399-S405.

103. Bartoloni A, Tomasoni L, Bartalesi F, Galli L, Sani S, Veloci S, Zammarchi L, Pini A, Castelli F: Combine intravenous treatment with artesunate and quinine for severe malaria in Italy. Am J Trop Med Hyg 2010, 83:274-276.

104. Ladhani S, Aibara RJ, Riordan FA, Shingadia D: Imported malaria in children: a review of clinical studies. Lancet Infect Dis 2007, 7:349-357.

105. Kurth F, Bélard S, Adegnika AA, Gaye O, Kremsner PG, Ramharter M: Do paediatric drug formulations of artemisinin combination therapies improve the treatment of children with malaria? A systematic review and meta-analysis. Lancet Infect Dis 2010, 10:125-132.

106. Morpeth SC, Ramadhani HO, Crump JA: Invasive non-Typhi Salmonella disease in Africa. Clin Infect Dis 2009, 49:606-611.

107. Ramharter M, Grobusch MP, Kiessling G, Adegnika AA, Möller U, Agnandji ST, Kramer M, Schwarz N, Kun JF, Oyakhirome S, Issifou S, Borrmann S, Lell B, Mordmüller B, Kremsner PG: Clinical and parasitological characteristics of puerperal malaria. J Infect Dis 2005, 191:1005-1009.

108. Schlagenhauf $P$, Blumentals WA, Suter P, Regep L, Vital-Durand G, Schaerer MT, Boutros MS, Rhein HG, Adamcova M: Pregnancy and fetal outcomes after exposure to mefloquine in the pre- and periconception period and during pregnancy. Clin Infect Dis 2012, 54:124-31.

109. McGready R, Lee S, Wiladphaingern J, Ashley E, Rijken M, Boel M, Simpson J, Paw M, Pimanpanarak M, Mu O, Singhasivanon P, White N, Nosten F: Adverse effects of falciparum and vivax malaria and the safety of antimalarial treatment in early pregnancy: a population-based study. Lancet Infect Dis 2012, 12:388-396.

110. Ramharter M, Oyakhirome $S$, Klein Klouwenberg $P$, Adégnika AA, Agnandji ST, Missinou MA, Matsiégui PB, Mordmüller B, Borrmann S, Kun JF, Lell B, Krishna S, Graninger W, Issifou S, Kremsner PG: Artesunate-clindamycin versus quinine-clindamycin in the treatment of Plasmodium falciparum malaria: a randomized controlled trial. Clin Infect Dis 2005, 40:1777-1784

111. Siswantoro H, Russell B, Ratcliff A, Prasetyorini B, Chalfein F, Marfurt J, Kenangalem H, Wuwung M, Piera KA, Ebsworth EP, Anstey NM, Tjitra E, Price $\mathrm{RN}$ : In vivo and in vitro efficacy of chloroquine against Plasmodium malariae and P. ovale in Papua, Indonesia. Antimicrob Agent Chemother 2011, 55:197-202.

112. Bassat Q: The use of artemether-lumefantrine for the treatment of uncomplicated Plasmodium vivax malaria. PLos Negl Trop Dis 2011, 5:e1325.

113. Mombo-Ngoma G, Kleine C, Basra A, Würbel H, Diop DA, Capan M, Adegnika AA, Kurth F, Mordmüller B, Joanny F, Kremsner PG, Ramharter M, Bélard S: Prospective evaluation of artemether-lumefantrine for the treatment of non-falciparum and mixed-species malaria in Gabon. Malar J 2012, 11:120

114. Pukrittayakamee S, Chantra A, Simpson JA, Vanijanonta S, Clemens R, Looareesuwan S, White NJ: Therapeutic responses to different antimalarial drugs in vivax malaria. Antimicrob Agent Chemother 2000, 44:1680-1685.

115. Taylor WR, Widjaja H, Richie TL, Basri H, Ohrt C, Tjitra, Taufik E, Jones TR, Kain KC, Hoffman SL: Chloroquine/doxycycline combination versus chloroquine alone and doxycycline alone for the treatment of Plasmodium falciparum and Plasmodium vivax malaria in north-eastern Irian Jaya, Indonesia. Am J Trop Med Hyg 2001, 64:223-228.

116. Fernando D, Rodrigo C, Rajapakse S: Primaquine in vivax malaria: an update and review on management issues. Malar J 2011, 10:351.

117. Centers for Disease Control and Prevention: Guidelines for Treatment of Malaria in the United States. 2012. http://www.cdc.gov/malaria/resources/ pdf/treatmenttable.pdf (Accessed 27th May 2012).

118. Baird JK, Hoffman SL: Primaquine therapy for malaria. Clin Infect Dis 2004, 39:1336-1345.

119. Leslie T, Mayan I, Mohammed N, Erasmus P, Kolaczinski J, Whitty CJ, Rowland M: A randomised trial of an eight-week, once weekly primaquine regimen to prevent relapse of Plasmodium vivax in Northwest Frontier Province. Pakistan. PLoS One. 2008, 3:e2861.

120. Betuela I, Bassat Q, Kiniboro B, Robinson L, Rosanas-Urgell A, Stanisic D, Siba PM, Alonso PL, Mueller I: Tolerability and safety of primaquine in Papua New Guinean children 1 to 10 years of age. Antimicrob Agents Chemother 2012, 56:2146-2149.

121. Singh B, Daneshvar C: Plasmodium knowlesi Malaria in Malaysia. Med J Malaysia 2010, 65:224-230.

122. Bray RS, Krotoski WA, Cogswell FB, Garnham PC, Rodriguez M, Guy MW, Gwadz RW, Sinden RE, Targett GA, Draper CC: Observations on early and late postsporozoite tissue stages in primate malaria. III. Further attempts to find early forms and to correlate hypnozoites with growing exo-erythrocytic schizonts and parasitaemic relapses in Plasmodium cynomolgi bastianellii infections. Trans R Soc Trop Med Hyg 1985, 79:269-273.

123. Anderios F, Noorrain A, Vythilingam I: In vivo study of human Plasmodium knowlesi in Macaca fascicularis. Exp Parasitol 2010, 124:181-189.

124. William T, Menon J, Rajaram G, Chan L, Ma G, Donaldsnon S, Khoo S, Fredrick C, Jelip J, Anstey NM, Yeo TW: Severe P. knowlesi malaria in a tertiary care hospital, Sabah, Malaysia. Emerg Infect Dis 2011, 17:1248-1255.

125. Byakika-Kibwika P, Lamorde M, Okaba-Kayom V, Mayanja-Kizza H, Katabira E, Hanpithakpong W, Pakker N, Dorlo TP, Tarning J, Lindegardh N, de Vries PJ, Back D, Khoo S, Merry C: Lopinavir/ritonavir significantly influences pharmacokinetic exposure of artemether/lumefantrine in HIV-infected Ugandan adults. J Antimicrob Chemother 2012, 67:1217-1223.

doi:10.1186/1475-2875-11-328

Cite this article as: Askling et al:: Management of imported malaria in Europe. Malaria Journal 2012 11:328. 